\title{
Determinan Perilaku Seksual Pra Nikah Remaja Pria di Indonesia Hasil SDKI
}

\author{
Sri Wahyuni ${ }^{1}$, Ikhsan Fahmi ${ }^{2}$ \\ 1,2Badan Pusat Statistik, Jakarta, Indonesia; swahyuni@bps.go.id; Jakarta; \\ ikhsan.fahmi@bps.go.id
}

\begin{abstract}
Abstrak
Perilaku seksual remaja merupakan masalah serius yang harus segera ditangani secara serius oleh pemerintah dan masyarakat. Data SDKI dan beberapa penelitian menunjukkan hubungan seksual pranikah lebih tinggi dilakukan remaja pria dibandingkan dengan remaja wanita. Hasil SDKI 2017 menunjukkan remaja pria yang pernah melakukan hubungan seksual pranikah sebesar 8 persen, dimana remaja pria umur 15-19 tahun sekitar 3,6 persen dan umur 20-24 tahun sekitar 14,0 persen. Tujuan dari penelitian ini adalah mengidentifikasi faktor-faktor yang mempengaruhi perilaku hubungan seksual pranikah yang dilakukan remaja pria di Indonesia. Metode yang digunakan adalah analisis regresi logistik binner, dengan menggunakan data SDKI 2017 Remaja Pria. Dalam penelitian ini dimasukkan sebelas variabel yang diduga berpengaruh pada perilaku hubungan seksual remaja pria. Hasil penelitian menunjukkan bahwa dengan tingkat kepercayaan 95 persen, terdapat delapan variabel yang signifikan mempengaruhi perilaku hubungan seksual remaja pria. Variabel tersebut adalah klasifikasi daerah tempat tinggal, merokok, konsumsi narkoba, pacaran, status masih sekolah, pendidikan tertinggi, komunikasi mengenai kesehatan reproduksi dengan saudara kandung, dan teman yang telah melakukan hubungan seksual sebelum menikah.
\end{abstract}

Kata Kunci: Perilaku Seksual Remaja Pria, SDKI 2017, Regresi Logistik

\section{Pendahuluan}

Saat ini remaja sedang mengalami perubahan sosial yang cepat menuju masyarakat modern, dan tentunya berpengaruh pada perilaku, normanorma, nilai-nilai dan gaya hidup mereka. Remaja mengalami perkembangan fisik maupun psikologis begitu pesat. Secara psikologis, biasanya ditandai dengan ketertarikan terhadap lawan jenis. Ketertarikan dengan lawan jenis kemudian berlanjut dengan pacaran, dan ironisnya banyak yang sudah melakukan hubungan seksual pra nikah. Hubungan 
seksual yang dilakukan remaja akan menimbulkan banyak resiko, antara lain resiko penyakit menular seksual, kehamilan pada usia dini yang tidak diinginkan, dan rusaknya moral serta perilaku remaja itu sendiri.

Hasil survei menunjukkan bahwa perilaku seksual dikalangan remaja pria saat ini cenderung meningkat. Hasil Survei Kesehatan Reproduksi Remaja Indonesia (SKRRI) 2007 menunjukkan remaja pria umur 15-19 tahun yang melakukan hubungan seksual sebanyak 3,7 persen dan umur 20-24 tahun sebanyak 10,5 persen. Angka ini meningkat, yang ditunjukkan dari hasil Survei Demografi dan Kesehatan Indonesia (SDKI) 2012 dimana remaja pria umur 15-19 tahun yang melakukan hubungan seksual sebanyak 4,5 persen dan umur 20-24 tahun sebanyak 14,6 persen. Angka ini sedikit menurun pada SDKI 2017, dimana remaja pria umur remaja pria umur 15-19 tahun sekitar 3,6 persen dan umur 20-24 tahun sekitar 14,0 persen. Ada beragam alasan remaja pria melakukan hubungan seksual, tiga alasan dengan persentase terbesar adalah alasan saling cinta sebanyak 46,1 persen, penasaran/ingin tahu sebanyak 34 persen, dan terjadi begitu saja sebanyak 15,4 persen.

Peningkatan perilaku seksual remaja harus segera ditangani, baik dengan kebijakan pemerintah maupun tindakan dari masyarakat. Untuk memperoleh metode penanganan yang tepat, melalui penelitian ini akan dilakukan identifikasi faktor-faktor yang mempengaruhi perilaku hubungan seksual pra nikah yang diakukan remaja pria.

\section{Metode Penelitian}

Remaja adalah masa pada saat individu berkembang dari pertama kali menunjukkan tanda-tanda sosial seksual sekundernya sampai saat mencapai kematangan seksual. Individu berkembang dari sisi psikologis dan pola identifikasi dari kanak- kanak menjadi dewasa. Terjadi peralihan dari ketergantungan sosial- ekonomi yang penuh pada keadaan yang relatif lebih mandiri Sarwono (2007). Batasan umur remaja berbedabeda menurut para peneliti maupun berbagai instansi. Menurut Sarwono (2007), pedoman umum untuk mengkategorikan remaja adalah batasan usia 11-24 tahun dan belum menikah. 
Penelitian ini menggunakan definisi remaja mengikuti SDKI 2017, dimana remaja merupakan pria atau wanita berumur 15-24 tahun yang belum kawin/ hidup bersama.

Analisis ini menggunakan raw data hasil SDKI 2017 dengan responden remaja pria berumur 15-24 tahun dan status belum kawin/hidup bersama. Metode analisis yang digunakan dalam penelitian ini adalah regresi logistik biner. Analisis regresi logistik digunakan untuk menjelaskan hubungan antara variabel tak bebas/respon/dependent yang berupa data dikotomik/biner dengan variabel bebas yang berupa data berskala interval dan atau kategorik (Hosmer dan Lemeshow, 1989). Variabel yang dikotomik/biner adalah variabel yang hanya mempunyai dua kategori saja, yaitu kategori yang menyatakan kejadian sukses $(Y=1)$ dan kategori yang menyatakan kejadian gagal $(\mathrm{Y}=0)$.

Untuk mengetahui pengaruh variabel bebas terhadap variabel tidak bebas secara bersama-sama (overall) di dalam model, dapat menggunakan Uji Likelihood Ratio. Sedangkan pengujian keberartian parameter (koefisien $\beta$ ) secara parsial dapat dilakukan melalui Uji Wald.

Odds ratio merupakan ukuran risiko atau kecenderungan untuk mengalami kejadian 'sukses' antara satu kategori dengan kategori lainnya, didefinisikan sebagai rasio dari odds untuk $X_{j}=1$ terhadap $X_{j}=0$. Odds ratio ini menyatakan risiko atau kecenderungan pengaruh observasi dengan $X_{j}=1$ adalah berapa kali lipat jika dibandingkan dengan observasi dengan $X_{j}=0$.

Variabel yang digunakan dalam analisis ini adalah sebagai berikut:

1) Variabel tak bebas (Y) : remaja pria pernah atau tidak melakukan hubungan seksual pra nikah (pernah $=1$; tidak pernah $=0$ )

2) Variabel bebas $(X)$ terdiri dari:
a. $\quad X_{1}$ : Klasifikasi daerah kota/desa $(1=$ perkotaan $; 0=$ perdesaan $)$
b. $\quad X_{2}$ : Partisipasi kerja (bekerja $=1$; tidak bekerja $=0$ )
c. $X_{3}: \operatorname{Merokok}(\mathrm{Ya}=1$; tidak $=0)$
d. $\quad X_{4}$ : Konsumsi narkoba (pernah $=1$; tidak pernah $=0$
e. $\quad X_{5}$ : Pernah pacaran $($ pernah $=1$; tidak pernah $=0$ ) 
f. $\quad X_{6}$ : Partisipasi sekolah (masih sekolah $=1$; tidak sekolah lagi $=$ $0)$

g. $\quad X_{7}$ : Pendidikan tertinggi yang ditamatkan (SLTA ke atas $=1$; maksimal SLTP $=0$ )

h. $\quad X_{8}$ : Komunikasi kesehatan reproduksi dengan ibu $(\mathrm{Ya}=1$; Tidak $=0)$

i. $\quad X_{9}$ : Komunikasi kesehatan reproduksi dengan bapak ( $\mathrm{Ya}=1$; Tidak $=0$ )

j. $\quad X_{10}$ : Komunikasi kesehatan reproduksi dengan saudara kandung $(\mathrm{Ya}=1$; Tidak $=0)$

k. $X_{11}$ : Mempunyai teman yang sudah melakukan hubungan seksual sebelum menikah $(\mathrm{Ya}=1$; Tidak $=0)$

Penelitian ini hanya terbatas pada hasil pengolahan raw data SDKI 2017 Remaja Pria dengan mempertimbangkan validitas data, sementara observasiobservasi yang mengandung missing value tidak disertakan dalam analisis.

\section{Hasil dan Pembahasan}

\subsection{Analisis Deskriptif}

Grafik 1 menunjukkan persentase remaja pria di perkotaan yang pernah melakukan hubungan seksual lebih kecil dibandingkan di perdesaan. Di perkotaan sebesar 7,4 persen, sedangkan di perdesaan sebesar 8,0 persen.

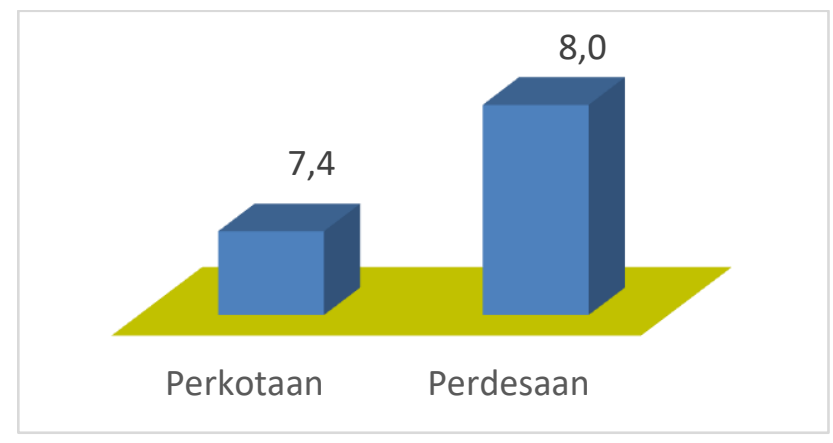

Gambar 1. Persentase Remaja Pria yang Melakukan Hubungan Seksual menurut Daerah Tempat Tinggal

Menurut partisipasi bekerja, sebagian remaja ada yang masih sekolah dan ada yang sudah bekerja. Hasil SDKI 2017 menunjukkan 61 persen remaja pria berstatus bekerja, sedangkan 39 persen sisanya tidak bekerja. Dari 
keseluruhan remaja pria yang bekerja, sekitar 10,5 persen diantaranya telah melakukan hubungan seksual pra nikah.

Kaitannya dengan perilaku merokok, lebih dari setengah remaja pria menjadi perokok (55,2 persen). Hasil SDKI 2017 menunjukkan remaja pria umur 15-19 tahun yang berstatus perokok saat ini sebesar 47,6 persen, sedangkan umur 20-24 tahun sebesar 67,2 persen. (BPS et al, 2018). Kenyataan ini sungguh memprihatinkan, dimana remaja yang usianya masih muda sudah terpapar dengan berbagai penyakit akibat merokok. Disamping itu, kebiasaan merokok juga akan berdampak buruk pada kesehatan orangorang yang ada di sekitarnya, yang biasa disebut sebagai perokok pasif.

Alkohol sudah tidak asing lagi di kalangan remaja. Data menunjukkan 37 persen remaja pria mengkonsumsi minuman beralkohol. Remaja pria umur 15-19 tahun sekitar 28,6 persen dan umur 20-24 hampir dua kali lipat persentasenya, yaitu 50,3 persen. Selain konsumsi alkohol, ada sebagian remaja yang sudah mengkonsumsi obat-obatan terlarang, sekitar 4,8 persen. Remaja pria umur 15-19 tahun sekitar 3 persen, sedangkan remaja pria umur 20-24 tahun memiliki persentase yang lebih besar, yakni 7,6 persen. Persentase remaja pria yang mengonsumsi obat-obatan terlarang di perkotaan lebih besar dibandingkan dengan di perdesaan.

Pacaran di kalangan remaja sudah menjadi hal biasa. ini ditunjukkan dengan data SDKI 2017 dimana sebagian besar remaja pria pernah pacaran, yaitu 83,9 persen. Pacaran menjadi jembatan pertemanan semakin akrab, hubungan dekat dalam berkomunikasi, serta membangun kedekatan emosi. Namun, seiring dengan semakin dekatnya hubungan remaja dalam ikatan pacaran akan beresiko pada perilaku yang menyimpang seperti bercumbu, ciuman, merangsang bagian tubuh yang sensitif, bahkan ada yang sampai melakukan hubungan seksual. Hasil SDKI 2017 menunjukkan 75,1 persen remaja yang berpacaran pernah pegangan tangan, yang berpelukan sebanyak 49,5 persen, yang berciuman bibir sebanyak 32,9 persen dan yang paling mengkhawatirkan remaja berani meraba ataupun diraba bagian tubuh yang sensitif sebanyak 21,5 persen.

Remaja perlu dibentuk dari sisi pola pikir, wawasan, sikap dan tanggung jawab melalui pendidikan. Harapannya, semakin tinggi tingkat pendidikan 
remaja akan mengurangi tindakan yang melanggar aturan, norma-norma dan nilai-nilai yang ada di lingkungan sekitarnya. Tingkat pendidikan remaja menunjukkan 10 persen remaja pria memilki tingkat pendidikan SD ke bawah, 51 persen tidak tamat SLTA dan 39 persen tamat SLTA ke atas. Dari data ini bisa dilihat bahwa tingkat pendidikan remaja masih sangat rendah. Kaitannya dengan perilaku seksual pra nikah, Grafik 2 memperlihatkan remaja pria yang yang melakukan hubungan seksual pra nikah menurut tingkat pendidikan.

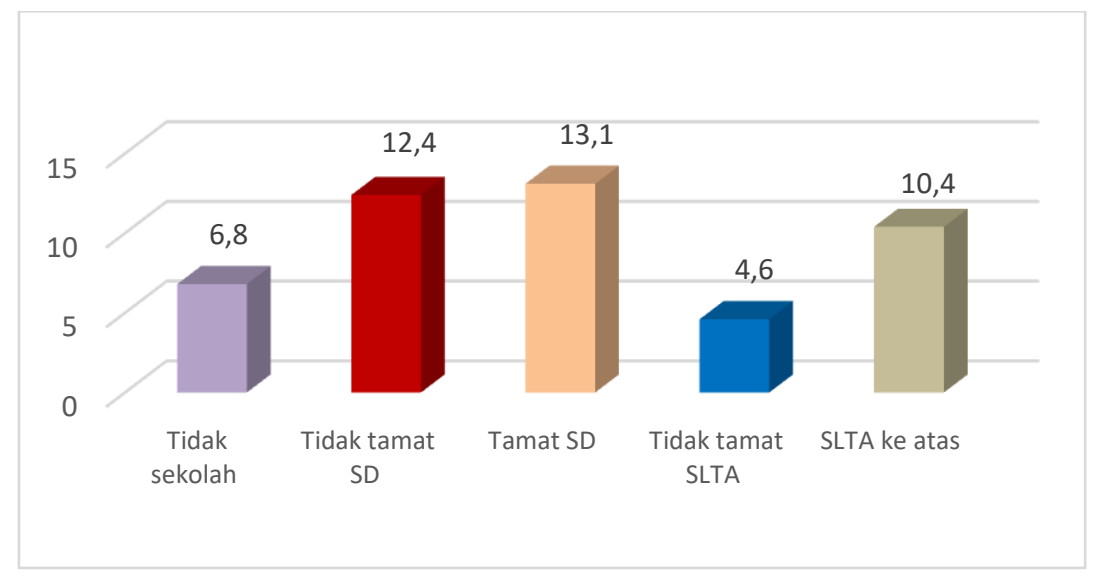

Gambar 2. Persentase remaja pria yang melakukan hubungan seksual menurut tingkat pendidikan

Kaitannya dengan peran orang tua, hubungan antara orang tua dengan anak sangat penting dalam membentuk karakter anak, dan menjadi sarana bagi orang tua untuk menjalin kedekatan dengan anaknya. Komunikasi yang baik akan memudahkan orang tua dan anak untuk saling berbagi cerita dan pengalaman, utamanya mengenai bagaimana pentingnya menjaga kesehatan reproduksi. Namun, masih banyak orang tua yang menganggap tabu dan malu membicarakan masalah seksual dengan anak-anaknya. Hal ini dibuktikan dengan hasil pendataan SDKI 2017 yang menunjukkan hanya 8,3 persen remaja pria yang berkomunikasi mengenai kesehatan reproduksi dengan bapaknya; 10,8 persen dengan ibunya.

Selain orang tua, pergaulan teman dan lingkungan sangat penting, karena akan berpengaruh pada sikap dan perilaku anak. Jika remaja mempunyai teman yang sudah melakukan hubungan seksual akan sangat rentan bagi remaja tersebut untuk mencoba melakukan hal serupa. Data menunjukkan 
54,8 persen remaja pria memiliki teman yang sudah pernah melakukan hubungan seksual.

\subsection{Hasil Analisis Regresi Logistik}

Untuk mendapatkan model yang fit dari analisis regresi logistik, maka dilakukan beberapa pengujian secara statistik yang meliputi overall test, goodness of fit test, dan partial test. Hasil pengujian simultan (overall test) menunjukkan nilai p-value 0,000 yang artinya dengan tingkat kepercayaan 95 persen, minimal ada satu variabel bebas yang berpengaruh pada variabel tak bebas. Kelayakan ataupun kesesuaian model dapat dilihat dari Hosmer and Lemeshow Test, dengan nilai sebesar 7,05 dengan p-value 0,5313 yang artinya dengan tingkat keyakinan 95 persen, dapat diyakini bahwa model yang digunakan mampu menjelaskan data. Selanjtnya, hasil pengujian parsial koefisien/penaksiran parameter disajikan dalam tabel berikut:

Tabel 1. Hasil Penaksiran Parameter

\begin{tabular}{lrrrr}
\hline \multicolumn{1}{c}{ Nama Variabel } & $\beta$ & S.E & Sig. & $\begin{array}{c}\text { Odds } \\
\text { Ratio }\end{array}$ \\
\hline 1. Klasifikasi Daerah Tempat Tinggal & $-0,400$ & 0,043 & 0,000 & 0,670 \\
\hline 2. Partisipasi Kerja & 0,830 & 0,090 & 0,318 & 1,087 \\
\hline 3. Merokok & 0,272 & 0,118 & 0,002 & 1,312 \\
\hline 4. Konsumsi Narkoba & 1,338 & 0,373 & 0,000 & 3,810 \\
\hline 5. Pernah pacaran & 2,898 & 6,942 & 0,000 & 18,141 \\
\hline $\begin{array}{l}\text { 6. Partisipasi sekolah } \\
\text { 7. Pendidikan tertinggi yang }\end{array}$ & $-0,874$ & 0,034 & 0,000 & 0,417 \\
\hline $\begin{array}{l}\text { ditamatkan } \\
\text { 8. Komunikasi kesehatan reproduksi }\end{array}$ & $-0,210$ & 0,060 & 0,005 & 0,811 \\
\hline $\begin{array}{l}\text { dengan Ibu } \\
\text { 9. Komunikasi kesehatan reproduksi } \\
\text { dengan Bapak }\end{array}$ & 0,064 & 0,152 & 0,650 & 1,067 \\
\hline $\begin{array}{l}\text { 10. Komunikasi kesehatan reproduksi } \\
\text { dengan Saudara Kandung }\end{array}$ & 0,370 & 0,135 & 0,000 & 1,448 \\
\hline $\begin{array}{l}\text { 11. Mempunyai teman yang sudah } \\
\text { melakukan hubungan seksual } \\
\text { sebelum menikah }\end{array}$ & 1,967 & 0,746 & 0,000 & 7,152 \\
\hline \begin{tabular}{l} 
12. Konstanta \\
\hline
\end{tabular} & $-5,991$ & 0,001 & 0,000 & 0,003 \\
\hline
\end{tabular}


Tabel 1 menunjukkan bahwa pada tingkat kepercayaan 95 persen, dari sebelas variabel yang dimasukkan dalam model, terdapat delapan variabel yang signifikan mempengaruhi perilaku hubungan seksual remaja pria dan tiga variabel yang tidak signifikan. Delapan variabel yang signifikan adalah klasifikasi daerah kota/desa, merokok, konsumsi narkoba, pernah pacaran, partisipasi sekolah, pendidikan tertinggi yang ditamatkan, komunikasi mengenai kesehatan reproduksi dengan saudara kandung, dan mempunyai teman yang sudah melakukan hubungan seksual sebelum menikah. Tiga variabel yang tidak signifikan adalah dan partisipasi kerja, komunikasi mengenai kesehatan reproduksi dengan ibu, dan komunikasi mengenai kesehatan reproduksi dengan bapak.

Merokok, konsumsi narkoba, pacaran, komunikasi kesehatan reproduksi dengan saudara kandung, dan memiliki teman yang pernah melakukan hubungan seksual sebelum menikah berkorelasi positif dengan perilaku seksual remaja pria dengan kecenderungan sebesar nilai odds ratio yang ditunjukkan pada setiap variabel pada Tabel 1. Sebagai contoh, nilai odds ratio variabel merokok sebesar $\operatorname{Exp}\left(\beta_{3}\right)=1,312$ artinya kecenderungan seorang remaja pria yang merokok untuk melakukan hubungan seksual 1,312 kali jika dibandingkan dengan remaja pria yang tidak merokok, dengan asumsi variabel lainnya dalam keadaan konstan. Demikian juga cara menginterpretasikan untuk variabel yang lainnya. Hasil temuan ini sejalan dengan penelitian Harbia, dkk (2018) mengenai dampak penyalahgunaan narkotika, psikotropika, dan zat adiitf lainnya (NAPZA) terhadap perilaku seks pranikah. Hasil penelitiannya menyebutkan bahwa residen penyalahgunaan jenis shabu akan meningkatkan kinerja seksual sehingga lebih lama dan agrefif.

Penelitian yang sama juga pernah dilakukan oleh Sitorus (2014), yang menyebutkan bahwa 61,3 persen pecandu narkotika telah melakukan hubungan seksual sebelum menikah, dan 54,7 persen melakukan hubungan seksual tersebut dengan pacarnya. Rony dan Nurhidayah (2008) dalam penelitiannya menyebutkan bahwa terdapat hubungan yang positif antara pacaran dengan perilaku seksual pranikah. Remaja yang berpacaran akan memiliki peluang yang tinggi terhadap perilaku seksual pranikah. 
Klasifikasi tempat tinggal, kegiatan masih sekolah, tingkat pendidikan berkorelasi negatif dengan perilaku seksual remaja pria. Artinya, semakin besar persentase remaja pria yang tinggal di perkotaan, remaja yang masih sekolah, maupun yang berpendidikan tinggi akan memiliki kecenderungan untuk tidak melakukan hubungan seksual pra nikah. Besarnya kecenderungan tersebut ditunjukkan dengan nilai odds ratio dari masingmasing variabel. Cara menginterpretasikannya, nilai odds ratio variabel klasifikasi tempat tinggal sebesar $\operatorname{Exp}\left(\beta_{1}\right)=0,670$ artinya kecenderungan seorang remaja pria yang tinggal di daerah perdesaan untuk melakukan hubungan seksual 1,5 kali jika dibandingkan dengan remaja pria yang tinggal di daerah perkotaan, dengan asumsi variabel lainnya dalam keadaan konstan.

Sekolah merupakan tempat dimana remaja yang masih bersekolah menghabiskan waktu yang cukup banyak. Dalam sehari siswa bisa berada di sekolah sekitar 8-10 jam. Maka dari itu, sekolah bisa dijadikan tempat yang penting dalam menyediakan informasi kesehatan reproduksi bagi remaja. Informasi kesehatan reproduksi tidak harus disampaikan pada saat jam belajar, namun bisa dijadikan sebagai kegiatan ekstrakurikuler atau pelajaran tambahan. Nandiya (2013) dalam Sesilia (2017) menyebutkan bahwa layanan guru bimbingan dan konseling di sekolah memiliki dampak positif bagi perkembangan siswa.

Setelah dilakukan pengujian, baik secara keseluruhan maupun parsial, maka diperoleh model regresi sebagai berikut:

$$
\begin{aligned}
Y(x)=\ln \left[\frac{\pi(1)}{1-\pi(1)}\right]= & -5,991-0,4 X_{1}+0,272 X_{3}+1,338 X_{4}+2,898 X_{5} \\
& -0,874 X_{6}-0,210 X_{7}+0,370 X_{10}+1,967 X_{11}+\varepsilon
\end{aligned}
$$

Keterangan:

$\mathrm{Y}=$ perilaku hubungan seksual remaja pria

$X_{1}=$ klasifikasi daerah tempat tinggal

$X_{3}=$ Merokok

$X_{4}=$ Konsumsi narkoba 
$X_{5}=$ Pernah pacaran

$X_{6}=$ Partisipasi sekolah

$X_{7}=$ Tingkat pendidikan tertinggi yang ditamatkan

$X_{10}=$ Berkomunikasi kesehatan reproduksi dengan saudara kandung

$X_{11}=$ Mempunyai teman yang sudah melakukan hubungan seksual sebelum nikah

\section{Simpulan}

Berdasarkan analisis regresi logistik diperoleh kesimpulan terdapat delapan variabel yang signifikan mempengaruhi perilaku hubungan seksual pra nikah yang dilakukan remaja pria di Indonesia dan tiga variabel tidak signifikan. Variabel yang signifikan adalah klasifikasi daerah tempat tinggal, merokok, konsumsi narkoba, pernah pacaran, masih sekolah, tingkat pendidikan, berkomunikasi mengenai kesehatan reproduksi dengan saudara kandung, dan mempunyai teman yang sudah melakukan hubungan seksual sebelum menikah.

Variabel yang secara positif mempengaruhi perilaku seksual remaja adalah merokok, konsumsi narkoba, pacaran, komunikasi kesehatan reproduksi dengan saudara kandung, dan memiliki teman yang pernah melakukan hubungan seksual sebelum menikah. Sedangkan variabel yang berpengaruh negatif adalah klasifikasi daerah tempat tinggal, partisipasi sekolah, dan pendidikan tertinggi yang ditamatkan.

Saran untuk penelitian berikutnya adalah menambah variabel pengetahuan remaja pria mengenai kesehatan reproduksi, pengetahuan remaja pria mengenai keluarga berencana (KB), dan tingkat ekonomi rumah tangga.

\section{Daftar Pustaka}

Agresti, A. 1990. Categorical Data Analysis, John Willey \& Sons, New York.

Anniswah, N. 2016. Faktor-Faktor yang Berhubungan dengan Perilaku Seksual Beresiko IMS pada Remaja Pria di Indonesia (Analisis Data Survei Demografi dan Kesehatan Indonesia, 2012), Skripsi, Program Studi Kesehatan Masyarakat, Fakultas Kedokteran dan Ilmu Kesehatan, Universitas Islam Negeri Syarif Hidayatullah, Jakarta 
BPS, BKKBN, Kementerian Kesehatan, ICF International. 2008. Survei Kesehatan dan Reproduksi Remaja Indonesia, Jakarta, Indonesia.

BPS, BKKBN, Kementerian Kesehatan, ICF International. 2013. Survei Demografi dan Kesehatan Indonesia : Kesehatan Reproduksi Remaja, Jakarta, Indonesia.

Cortez R, Saadat S, Marinda E, Oluwole O. Adolescent Sexual and Reproductive Health in Nigeria. HNPGP Knowledge Brief. World Bank. 2015: 1-4.

Harbia, Multazam M, Asrina A. 2018. Dampak Penyalahgunaan Narkotika, Psikotropika dan Zat Aditif Lainnya (NAPZA) terhadap Perilaku Seks Pranikah. Window of Health : Jurnal Kesehatan, Vol. 1 No. 3 (Juli 2018).

Hingson, R., Timothy H., Michael R., Henry W. 2003. Early Age of First Drunkenness as a Factor in College Students' Unplanned and Unprotected Sex Attribute to Drinking, Pediatrics, Vol 111, no $1: 34-41$

Hosmer, D. W. dan Lemeshow, S. 2000. Applied Logistic Regression, John Willey \& Sons, New York.

Indraprasti, D dan Rachmawati, M, A. 2008. Hubungan antara Kontrol Diri dengan Perilaku MInum-Minuman Keras pada Remaja Laki-Laki, Universitas Islam Indonesia, Yogyakarta.

Lisnawati dan Lestari, N. S. 2015. Faktor-Faktor yang Berhubungan dengan Perilaku Seksual Remaja di Cirebon, Jurnal CARE, Vol. 3, No. 1, 2015.

Nurhayati, A., Fajar, A.N., Yeni. 2017. Determinan Perilaku Seksual Pranikah pada Remaja SMA Negeri 1 Indralaya Utara, Jurnal Ilmu Kesehatan Masyarakat, Juli 2017, 8(2):83-90.

Rianto, E., Priwahyuni, Y., Saputra, B. 2018. Determinan Perilaku Seksual Remaja di SMA Negeri 1 Siak Kecil Kabupaten Bengkalis Tahun 2017, The Indonesian Journal of Health Science, Vol. 10, No. 1, Juni 2018

Rony S, Nurhidayah S. 2008. Pengaruh Pacaran terhadap Perilaku Seks Pranikah. Jurnal Soul, Vol. 1, No. 2, September 2008.

Sarwono, S.W. 2007. Psikologi Remaja. Jakarta: Raja Grafindo Persada. Hal. 24-25, 52-58, 142-165. 
Sesilia, Y.H, Ismael, S., Iskandar, A. 2017. Perilaku Pacaran Remaja dan Faktor-Faktor yang Mempengaruhi di SMAN 1 dan SMAN 2 Kecamatan Meliau. Jurnal Mahasiswa dan Penelitian Kesehatan. http://openjurnal.unmuhpnk.ac.id/index.php/JJUM

Soetjiningsih. 2004. Tumbuh Kembang Remaja dan Permasalannya. Jakarta: Sagung Seto. Hal. 20-30.

Sitorus RJ. 2015. Pengaruh Tahapan Rehabilitasi Terhadap Self Efficacy Pasien Ketergantungan Narkotika Di Pusat Terapi dan Rehabilitasi Lido. Depok: Universitas Indonesia; 2015 